\title{
Different Response to Cd2+ Adsorption by Alkali- modified Biochars Derived From Soybean Straw and Rape Straw
}

\section{Yaxin Kang}

Nanjing Agricultural University - Weigang Campus: Nanjing Agricultural University

\section{Yi Zhou}

Nanjing Agricultural University - Weigang Campus: Nanjing Agricultural University Hao Li

Nanjing Agricultural University - Weigang Campus: Nanjing Agricultural University

Shanguo Chen

Nanjing Agricultural University - Weigang Campus: Nanjing Agricultural University

\section{Fenghua Tian}

Nanjing Agricultural University - Weigang Campus: Nanjing Agricultural University

Lianqing Li ( $\square$ lqli@njau.edu.cn )

Nanjing Agricultural University - Weigang Campus: Nanjing Agricultural University https://orcid.org/0000-0003-1656-1235

\section{Marios Drosos}

Nanjing Agricultural University - Weigang Campus: Nanjing Agricultural University

\section{Stephen Joseph}

Nanjing Agricultural University - Weigang Campus: Nanjing Agricultural University

\section{Genxing Pan}

Nanjing Agricultural University - Weigang Campus: Nanjing Agricultural University

\section{Research Article}

Keywords: Biochar, Cadmium, Alkali modification, Adsorption mechanism

Posted Date: April 5th, 2021

DOl: https://doi.org/10.21203/rs.3.rs-167467/v1

License: (c) (1) This work is licensed under a Creative Commons Attribution 4.0 International License. Read Full License 
4 Yaxin Kang ${ }^{\text {a }}$, Yi Zhou ${ }^{\text {a }}$, Hao Li ${ }^{\text {a }}$, Shanguo Chen ${ }^{\text {a }}$, Fenghua Tian ${ }^{\text {a }}$, Lianqing Li ${ }^{\text {a**, }}$, Marios Drosos

$5 \quad$ a, Stephen Joseph ${ }^{\mathrm{a}, \mathrm{b}}$, Genxing Pan ${ }^{\mathrm{a}}$

6

$7 \quad{ }^{a}$ Institute of Resources, Ecosystem and Environment of Agriculture and Center of Biochar and

8 Green Agriculture, Nanjing Agricultural University, 1 Weigang, Nanjing 210095, China

$9 \quad{ }^{b}$ School of Materials Science and Engineering, University of New South Wales, Sydney, NSW 2052,

10 Australia

11

* Corresponding author at: Institute of Resources, Ecosystem and Environment of Agriculture and Center of Biochar and Green Agriculture, Nanjing Agricultural

14 University, 1 Weigang, Nanjing 210095, China.

Tel/Fax: +86 2584398657

E-mail address: lqli@njau.edu.cn (L. Li). 
Abstract

Biochars have been modified by alkali $\left(\mathrm{Ca}(\mathrm{OH})_{2}\right)$ to enhance $\mathrm{Cd}$ sorption capacity in aqueous solution. In this research, the alkali-modified $(\mathrm{Ca})$ biochars were prepared by co-pyrolyzing lime $\left(\mathrm{Ca}(\mathrm{OH})_{2}\right)$ and soybean straw $(\mathrm{SBB})$ or rape straw $(\mathrm{RSB})$ at $450^{\circ} \mathrm{C}$. The absorption mechanism was investigated by a series of experiments and was provided by quantitative analysis. The maximum adsorption capacities of $\mathrm{Cd}^{2+}$ by $\mathrm{Ca}-\mathrm{SBB}$ and $\mathrm{Ca}-\mathrm{RSB}$ were calculated to be $78.49 \mathrm{mg} \mathrm{g}^{-1}$ and 49.96 $\mathrm{mg} \mathrm{g}^{-1}$, which were 1.56 and 1.48 times higher than SBB (50.40 $\left.\mathrm{mg} \mathrm{g}^{-1}\right)$ and RSB (33.79 $\left.\mathrm{mg} \mathrm{g}^{-1}\right)$, respectively. Compared with the original biochar (SBB, RSB), alkali-modified biochars (Ca-SBB and Ca-RSB) were found to have faster adsorption kinetics and lower desorption efficiencies. The mechanism study indicated that $\mathrm{Ca}(\mathrm{OH})_{2}$ modification effectively enhanced the contribution of ion exchange and decreased the contribution of functional groups complexation. After $\mathrm{Ca}(\mathrm{OH})_{2}$ modification, precipitation and ion exchange mechanisms dominated $\mathrm{Cd}^{2+}$ absorption on Ca-SBB, accounting for $49.85 \%$ and $34.94 \%$ of the total adsorption, respectively. Similarily ion exchange and precipitation were the main adsorption mechanism on Ca-RSB, accounting however for $61.91 \%$ and $18.47 \%$ of total adsorption, respectively. These results suggested that alkali-modified biochars have great potential in adsorbing cadmium in wastewater.

Keywords: Biochar ; Cadmium ; Alkali modification ; Adsorption mechanism 40 
1. Introduction

Cadmium $(\mathrm{Cd})$ is one of the most toxic inorganic pollutants in wastewater and soil because of its strong migration and enrichment ability, which causes severe damage to human health (Patar, et al. 2016). Several technologies have been used to remove Cd from wastewater and soil solution such as precipitation, complexation and adsorption (Bolan, et al. 2014; Fu and Wang 2011). Considering the removal efficiency, easy operation and secondary pollution, adsorption method is considered to be the best one (Burakov, et al. 2018).

Biochar, a solid product prepared by biomasses pyrolysis under oxygen-limited conditions (Lehmann 2007), has been reported to sequestrate carbon, improve soil quality and increase crop yield (Lehmann 2007; Woods, et al. 2006; Zhang, et al. 2010). The deepening of biochar research revealed its great potential in the treatment of heavy metal pollution in water and soil, due to its well-developed pore structure, generally high $\mathrm{pH}$, abundant oxygen-containing functional groups and mineral components (Ahmad, et al. 2014; Bian, et al. 2014; Li, et al. 2017). Cd absorption capacity of biochar estimated to be $0.3-39.1 \mathrm{mg} \mathrm{g}^{-1}$ (Inyang, et al. 2016). Biochar soil amendment was found consistently and significantly to increase soil $\mathrm{pH}$ and decrease soil extractable $\mathrm{Cd}$ over a 3-year period experiment (Bian, et al. 2014). Based on the current research, the $\mathrm{Cd}^{2+}$ adsorption mechanisms on biochar included metal ion exchange, mineral precipitation, functional groups complexation and $\mathrm{Cd}^{2+}-\pi$ coordination (Trakal, et al. 2014; Wang, et al. 2018; Yu, et al. 2018; Zhang, et al. 2015).

Though biochar is an environmentally friendly adsorbent for Cd removal from water, the $\mathrm{Cd}^{2+}$ absorption capacity of biochar is generally lower compared with other bio sorbents such as activated carbon (Inyang, et al. 2016; Wilson, et al. 2006). In order to improve its adsorption performance, it 
is necessary to modify it through loading with minerals, organic functional groups, nano-particles and activation with alkali solutions (Ahmed, et al. 2016). In all modification methods, loading minerals on the surface of biochar is the most promising one, combining the advantages of biochar and minerals (Tan, et al. 2016). Lime $\left(\mathrm{Ca}(\mathrm{OH})_{2}\right)$ is the most common passivator used to remove $\mathrm{Cd}^{2+}$ from wastewater and soil solution, due to its affordable price and availability (Fu and Wang 2011). Therefore, in order to reduce the cost and improve the Cd adsorption performance, copyrolysis of straw and $\mathrm{Ca}(\mathrm{OH})_{2}$ is a feasible and easy-to-operate method. Biochar prepared by copyrolysis of $\mathrm{Ca}(\mathrm{OH})_{2}$ and sludge improved the surface area, DOC content and alkalinity (Ren, et al. 2018). However, there is still a lack of quantitative research on the relative distribution of $\mathrm{Cd}^{2+}$ adsorption mechanisms in alkali-modified biochar.

In this study, the alkali-modified biochars were prepared by co-pyrolyzing lime $\left(\mathrm{Ca}(\mathrm{OH})_{2}\right)$ and straw (rape straw or soybean straw), and were then used to quantify $\mathrm{Cd}^{2+}$ adsorption and reveal its binding mechanism. The purposes of the study are 1) to investigate the $\mathrm{Cd}$ adsorption performance and the contribution of different binding mechanisms of alkali-modified biochars produced from rape straw and soybean straw, respectively; and 2) to compare the different response to $\mathrm{Cd}^{2+}$ adsorption by two kinds of alkali-modified biochars.

2. Materials and methods

\subsection{Materials}

Rape straw and soybean straw were collected from an agricultural market in Nanjing. All chemicals were of analytical grade and all solutions were made with deionized water (DI). Cadmium nitrate $\left(\mathrm{Cd}\left(\mathrm{NO}_{3}\right)_{2} \cdot 4 \mathrm{H}_{2} \mathrm{O}\right)$ and sodium nitrate $\left(\mathrm{NaNO}_{3}\right)$ were purchased from Aladdin Biochemical Technology Co. , Ltd, Shanghai, China. Lime $\left(\mathrm{Ca}(\mathrm{OH})_{2}\right)$ was purchased from Xilong Scientific Co., 
Ltd, Guangdong, China.

\subsection{Biochar preparation}

The dried rape and soybean straw were placed in a stainless steel reactor and heated in a muffle furnace under oxygen-limited condition at $450^{\circ} \mathrm{C}$ for $2 \mathrm{~h}$. The biochars originated from rape straw and soybean straw were referred to as RSB and SBB, respectively. The alkali-modified biochars were prepared by heating rape straw or soybean straw together with lime $\left(\mathrm{Ca}(\mathrm{OH})_{2}\right)$ at $450{ }^{\circ} \mathrm{C}$ for 2 h. Specifically, alkali-modified biochars were originated from rape straw or soybean straw mixed with $\mathrm{Ca}(\mathrm{OH})_{2}$ in a ratio of 1:0.028 (straw/Ca, w/w). The alkali-modified biochars derived from rape straw and soybean straw were referred to as Ca-RSB and Ca-SBB, respectively. The tested biochars were ground and passed through $0.5-\mathrm{mm}$ sieve for later testing. The biochar samples were demineralized by rinsing with $1 \mathrm{M} \mathrm{HCl}$ followed by washing with DI until the $\mathrm{pH}$ became constant (Wang, et al. 2015).

\subsection{Characterization of biochars}

Biochars $\mathrm{pH}$ values were measured using a digital $\mathrm{pH}$ meter. Cation exchange capacity (CEC) was analyzed using ammonium acetate exchange method by flame spectrophotometer (Gaskin, et al. 2008), and dissolved organic carbon (DOC) was measured by total organic carbon analyzer (TOC) (Jena Multi N/C 2100) at a ratio of $1.0 \mathrm{~g}$ biochar in $20 \mathrm{~mL}$ DI water after $24 \mathrm{~h}$ equilibrium. Total C, $\mathrm{H}$ and $\mathrm{N}$ contents of biochars were determined by an elemental analyzer (Vario EL cube). The content of $\mathrm{K}, \mathrm{Ca}, \mathrm{Na}, \mathrm{Mg}, \mathrm{P}$ and $\mathrm{S}$ was determined by inductively coupled plasma-optical emission spectroscopy (ICP-OES) (Agilent 710). Specific surface area and pore properties of biochars were measured using a surface area and porosity analyzer (Micromeritics Tristar II 3020, USA). The characteristics of biochars are given in more details in Table S1. 

simultaneously with the SEM at the same surface locations using energy dispersive X-ray spectroscopy (EDS, AZtec X-Max 50). X-ray diffraction (XRD) patterns were collected using a powder X-ray diffractometer (XRD, $\mathrm{X}^{`}$ Pert MPD) to determine possible mineral formation within the biochar. Fourier-transform infrared (FTIR) spectra (Nicolet 8700) were also collected in the $400-4000 \mathrm{~cm}^{-1}$ range to identify the organic functional groups present in the biochars' surface.

\subsection{Sorption experiments}

Cadmium stock solution (1000 $\left.\mathrm{mg} \mathrm{L}^{-1}\right)$ was prepared by dissolving cadmium nitrate

$\left(\mathrm{Cd}\left(\mathrm{NO}_{3}\right)_{2} \cdot 4 \mathrm{H}_{2} \mathrm{O}\right)$ in $0.01 \mathrm{~mol} \mathrm{~L}^{-1} \mathrm{NaNO}_{3}$ solution. Adsorption kinetics experiments were carried out by adding $0.1 \mathrm{~g}$ biochar samples to $25 \mathrm{~mL}$ solutions containing $100 \mathrm{mg} \mathrm{L}^{-1} \mathrm{Cd}^{2+}$ agitated at a speed of $180 \mathrm{rpm}$. Each sample was extracted at different time intervals $(5,15,30,60,120,240,480$ and $720 \mathrm{~min})$. Sorption kinetics were evaluated at room temperature $\left(25^{\circ} \mathrm{C}\right)$ and the initial $\mathrm{pH}$ value was adjusted to $5.0 \pm 0.05$ by adding $0.1 \mathrm{M} \mathrm{HNO}_{3}$ or $0.1 \mathrm{M} \mathrm{NaOH}$. Adsorption isotherm experiments were studied with initial $\mathrm{Cd}^{2+}$ concentrations in the range of $10-300 \mathrm{mg} \mathrm{L}^{-1}$ at $\mathrm{pH} 5.0$ for $12 \mathrm{~h}$. agent at $25{ }^{\circ} \mathrm{C}$ for $12 \mathrm{~h}$. The final suspensions were filtered by $0.45 \mu \mathrm{m}$ filter papers and the supernatant solution was separated for analysis of $\mathrm{Cd}^{2+}$ using flame atomic absorption

$$
\mathrm{Q}_{\mathrm{e}}=\left(\mathrm{C}_{0}-\mathrm{C}_{\mathrm{e}}\right) * \mathrm{~V} / \mathrm{m}
$$


$\mathrm{Q}_{\mathrm{d}}=\left(\mathrm{C}_{\mathrm{de}}-\mathrm{C}_{\mathrm{d} 0}\right) * \mathrm{~V} / \mathrm{m}$

$\%$ desorption $=\mathrm{Q}_{\mathrm{d}} / \mathrm{Q}_{\mathrm{e}}{ }^{*} 100 \%$

where $\mathrm{C}_{0}$ and $\mathrm{C}_{\mathrm{e}}$ are the initial and equilibrium concentration $\left(\mathrm{mg} \mathrm{L}^{-1}\right)$ during adsorption, and

$\mathrm{C}_{\mathrm{d} 0}$ and $\mathrm{C}_{\mathrm{de}}$ are the initial and equilibrium concentration $\left(\mathrm{mg} \mathrm{L}^{-1}\right)$ during desorption, respectively.

$$
\begin{aligned}
& Q_{t}=Q_{e}\left(1-e^{-k 1 t}\right) \\
& \mathrm{Q}_{\mathrm{t}}=\mathrm{k}_{2} \mathrm{Q}_{\mathrm{e}}{ }^{2} \mathrm{t} /\left(1+\mathrm{k}_{2} \mathrm{Q}_{\mathrm{e}} \mathrm{t}\right) \\
& \mathrm{Q}_{\mathrm{t}}=\mathrm{K}_{\mathrm{p}} \mathrm{t}^{0.5}+\mathrm{C} \\
& \mathrm{Q}_{\mathrm{e}} / \mathrm{Q}_{\max }=\mathrm{BC}_{\mathrm{e}} /\left(1+\mathrm{BC}_{\mathrm{e}}\right) \\
& \mathrm{Q}_{\mathrm{e}}=\mathrm{KC}_{\mathrm{e}}{ }^{1 / \mathrm{n}}
\end{aligned}
$$

where $\mathrm{Q}_{\mathrm{e}}$ and $\mathrm{Q}_{\mathrm{t}}$ are the adsorption capacity $\left(\mathrm{mg} \mathrm{g}^{-1}\right)$ at equilibrium and time $\mathrm{t}$, respectively. $\mathrm{k}_{1}$ $\left(\mathrm{h}^{-1}\right), \mathrm{k}_{2}\left(\mathrm{mg} \mathrm{g}^{-1} \mathrm{~h}^{-1}\right)$ and $\mathrm{K}_{\mathrm{p}}\left(\mathrm{mg} \mathrm{g}^{-1} \mathrm{~h}^{-0.5}\right)$ indicate the rate constants corresponding to the respective kinetic model. $\mathrm{C}_{\mathrm{e}}$ is the residual $\mathrm{Cd}^{2+}$ concentration $\left(\mathrm{mg} \mathrm{L}^{-1}\right)$ at equilibrium. $\mathrm{Q}_{\max }$ is the maximum adsorption capacity $\left(\mathrm{mg} \mathrm{g}^{-1}\right) ; \mathrm{B}\left(\mathrm{L} \mathrm{mg}^{-1}\right)$ and $\mathrm{K}\left(\mathrm{L} \mathrm{g}^{-1}\right)$ are the rate constants corresponding to the respective isotherm model, and $\mathrm{n}$ represents the degree of nonlinearity between solution concentration and adsorption.

As described in Section 2.4, 0.05g untreated-biochar and demineralized biochar were mixed with $25 \mathrm{~mL}$ solutions containing $250 \mathrm{mg} \mathrm{L}^{-1} \mathrm{Cd}^{2+}$, respectively. After adsorption, the concentrations 
147

of $\mathrm{K}^{+}, \mathrm{Ca}^{2+}, \mathrm{Na}^{+}, \mathrm{Mg}^{2+}$ and $\mathrm{Cd}^{2+}$ in the filtrate were measured by fire photometer and FAAS. The biochars loaded with and without $\mathrm{Cd}^{2+}$ were prepared for a series of analysis such as SEM-EDS, $\mathrm{XRD}$ and FTIR. The adsorption capacity due to mineral precipitation $\left(\mathrm{Q}_{\mathrm{cmp}}\right)$, cation exchange $\left(\mathrm{Q}_{\mathrm{cme}}\right)$, functional groups complexation $\left(\mathrm{Q}_{\mathrm{co}}\right), \mathrm{Cd}^{2+}-\pi$ coordination $\left(\mathrm{Q}_{\mathrm{c} \pi}\right)$ and the total $\mathrm{Cd}$ adsorption capacity $\left(\mathrm{Q}_{\mathrm{ct}}\right)$ were calculated according to Wang, et al. (2015) and Cui, et al. (2016). In more details:

(i) Most of minerals in biochars were removed by using $1 \mathrm{M} \mathrm{HCl}$ solution. The adsorption capacity due to minerals $\mathrm{Q}_{\mathrm{cm}}\left(\mathrm{mg} \mathrm{g}^{-1}\right)$ was calculated as the difference in adsorption capacity of $\mathrm{Cd}^{2+}$ between untreated and demineralized biochars (Eq. (9)).

$$
\mathrm{Q}_{\mathrm{cm}}=\mathrm{Q}_{\mathrm{ct}}-\mathrm{Q}_{\mathrm{ca}} * \mathrm{Y}
$$

5

where $\mathrm{Q}_{\mathrm{ca}}$ is the adsorption capacity of demineralized biochars $\left(\mathrm{mg} \mathrm{g}^{-1}\right)$ and $\mathrm{Y}$ is the yield of demineralized biochar from untreated biochar.

(ii) $\mathrm{Q}_{\mathrm{cme}}$ was estimated by the net release of cations $\left(\mathrm{K}^{+}, \mathrm{Ca}^{2+}, \mathrm{Na}^{+}, \mathrm{Mg}^{2+}\right)$ in solution before and after adsorption (Eq. (10)).

$$
\mathrm{Q}_{\mathrm{cme}}=\mathrm{Q}_{\mathrm{k}}+\mathrm{Q}_{\mathrm{Ca}}+\mathrm{Q}_{\mathrm{Na}}+\mathrm{Q}_{\mathrm{Mg}}
$$

where $\mathrm{Q}_{\mathrm{k}}, \mathrm{Q}_{\mathrm{Ca}}, \mathrm{Q}_{\mathrm{Na}}, \mathrm{Q}_{\mathrm{Mg}}$ are the adsorption capacity by net release amount of $\mathrm{K}^{+}, \mathrm{Ca}^{2+}, \mathrm{Na}^{+}$ and $\mathrm{Mg}^{2+}$ during the $\mathrm{Cd}$ adsorption process, respectively $\left(\mathrm{mg} \mathrm{g}^{-1}\right)$.

(iii) $\mathrm{Cd}^{2+}$ sorption on minerals was the result of interaction between ion exchange and mineral precipitation, so $\mathrm{Q}_{\mathrm{cmp}}$ could be obtained by the difference between $\mathrm{Q}_{\mathrm{cm}}$ and $\mathrm{Q}_{\mathrm{cme}}$ value:

$$
\mathrm{Q}_{\mathrm{cmp}}=\mathrm{Q}_{\mathrm{cm}}-\mathrm{Q}_{\mathrm{cme}}
$$

(iv) $\mathrm{Q}_{\mathrm{co}}$ was calculated by the difference in the $\mathrm{pH}$ value of demineralized biochars before and after the adsorption :

$$
\mathrm{Q}_{\mathrm{co}}=\mathrm{Q}_{\mathrm{co} 1} * \mathrm{Y}
$$



demineralized biochars $\left(\mathrm{mg} \mathrm{g}^{-1}\right)$. the $\mathrm{Q}_{\mathrm{co}}$ value:

$$
\mathrm{Q}_{\mathrm{c} \pi}=\mathrm{Q}_{\mathrm{a}} * \mathrm{Y}-\mathrm{Q}_{\mathrm{co}}
$$

\subsection{Statistical analysis}

All the experiments were conducted in triplicates. Test data are expressed as mean \pm standard deviation and use Origin $2020 \mathrm{~b}$ software to draw graphics. The significant difference was compared with the least square mean student's $\mathrm{t}(\mathrm{P}<0.05)$ by JMP 11.0 (two-tailed).

\subsubsection{Kinetics of $\mathrm{Cd}^{2+}$ absorption on biochars} adsorption capacity within $8 \mathrm{~h}$. Compared with SBB, Ca-SBB had a faster adsorption rate for $\mathrm{Cd}$ and reached equilibrium within a few minutes (Fig. 1a). Similarly, the $\mathrm{Cd}^{2+}$ absorption on Ca-RSB raised rapidly in the first 30 min and reached adsorption equilibrium faster than RSB (Fig. 1b). 

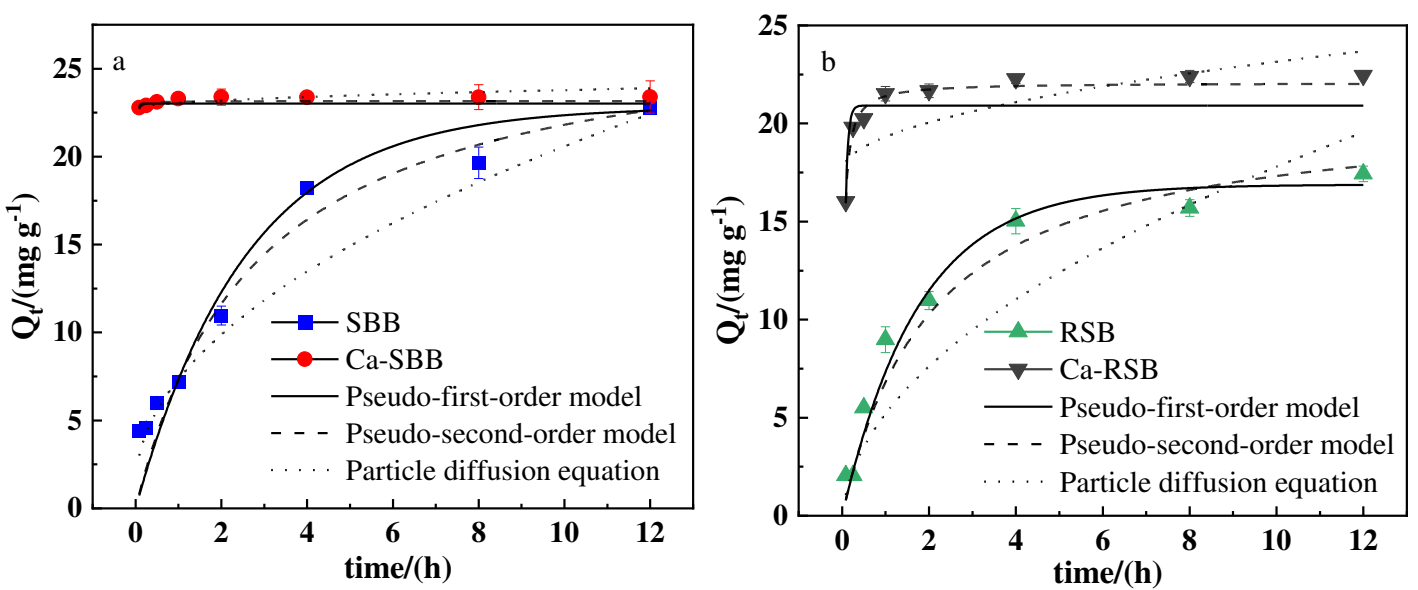

186

Fig. 1 Sorption kinetic of $\mathrm{Cd}^{2+}$ on SBB, Ca-SBB (a) and RSB, Ca-RSB (b), respectively. $\mathrm{Q}_{\mathrm{t}}$

$\left(\mathrm{mg} \mathrm{g}^{-1}\right)$ is the amount of metal adsorbed per unit weight of adsorbent

189 Table 1 The regression parameter of kinetics equation for the adsorption of $\mathrm{Cd}^{2+}$ onto biochars

\begin{tabular}{|c|c|c|c|c|c|c|c|c|}
\hline \multirow[t]{3}{*}{ Biochars } & \multicolumn{3}{|c|}{ Pseudo-first-order model } & \multicolumn{3}{|c|}{ Pseudo-second-order model } & \multicolumn{2}{|c|}{ Particle diffusion equation } \\
\hline & $\mathrm{Q}_{\mathrm{e}}$ & $\mathrm{k}_{1}$ & $\mathrm{R}^{2}$ & $\mathrm{Q}_{\mathrm{e}}$ & $\mathrm{k}_{2}$ & $\mathrm{R}^{2}$ & $\mathrm{k}_{\mathrm{p}}$ & $\mathrm{R}^{2}$ \\
\hline & $\mathrm{mg} \mathrm{g}^{-1}$ & $\mathrm{~h}^{-1}$ & & $\mathrm{mg} \mathrm{g}^{-1}$ & $\mathrm{~g} \mathrm{mg}^{-1} \mathrm{~h}^{-1}$ & & $\mathrm{mg} \mathrm{g}^{-1} \mathrm{~h}^{-0}$ & \\
\hline SBB & 24.07 & 0.356 & 0.986 & 26.98 & 0.016 & 0.997 & 6.86 & 0.983 \\
\hline RSB & 16.33 & 0.509 & 0.965 & 18.51 & 0.040 & 0.974 & 5.24 & 0.927 \\
\hline $\mathrm{Ca}-\mathrm{SBB}$ & 23.31 & 38.50 & 0.445 & 23.34 & 17.87 & 0.999 & 0.824 & 0.561 \\
\hline Ca-RSB & 21.58 & 15.60 & 0.831 & 22.28 & 1.343 & 0.981 & 1.40 & 0.548 \\
\hline
\end{tabular}

190 Note: Qe are the calculated data $\left(\mathrm{mg} \mathrm{g}^{-1}\right) ; \mathrm{k}_{1}, \mathrm{k}_{2}, \mathrm{k}_{\mathrm{p}}$ is the rate constant for pseudo-first-order model

$191\left(\mathrm{~h}^{-1}\right)$, pseudo-second-order model $\left(\mathrm{g} \mathrm{mg}^{-1} \mathrm{~h}^{-1}\right)$ and particle diffusion equation $\left(\mathrm{mg} \mathrm{g}^{-1} \mathrm{~h}^{-0.5}\right)$

192

193 3.1.2. Isotherms of $\mathrm{Cd}^{2+}$ sorption on biochars

194 The adsorption isotherms of $\mathrm{Cd}^{2+}$ were illustrated in Fig. 2. At low $\mathrm{Cd}^{2+}$ concentrations, a sharp

195 slope appeared. After that, the biochars became saturated reaching steady state conditions.

196 The fitted parameters reported in Table 2 indicated that, the equilibrium sorption data of SBB 
197

198

199

200

201

202

203

204

205

206

207

208

and Ca-SBB well fitted to the Langmuir model with $\mathrm{R}^{2}$ values than the Freundlich model. In particular, the $\mathrm{Q}_{\max }$ value for Ca-SBB was 1.56 times larger than that for SBB. However, in the cases of the biochar samples RSB and Ca-RSB, both the Langmuir and Freundlich models display high $\mathrm{R}^{2}(>0.98)$ values. The Langmuir maximum sorption quantity $\left(\mathrm{Q}_{\max }\right)$ of $\mathrm{Cd}^{2+}$ for Ca- $\mathrm{RSB}$ was about 1.48 times greater than that for RSB.
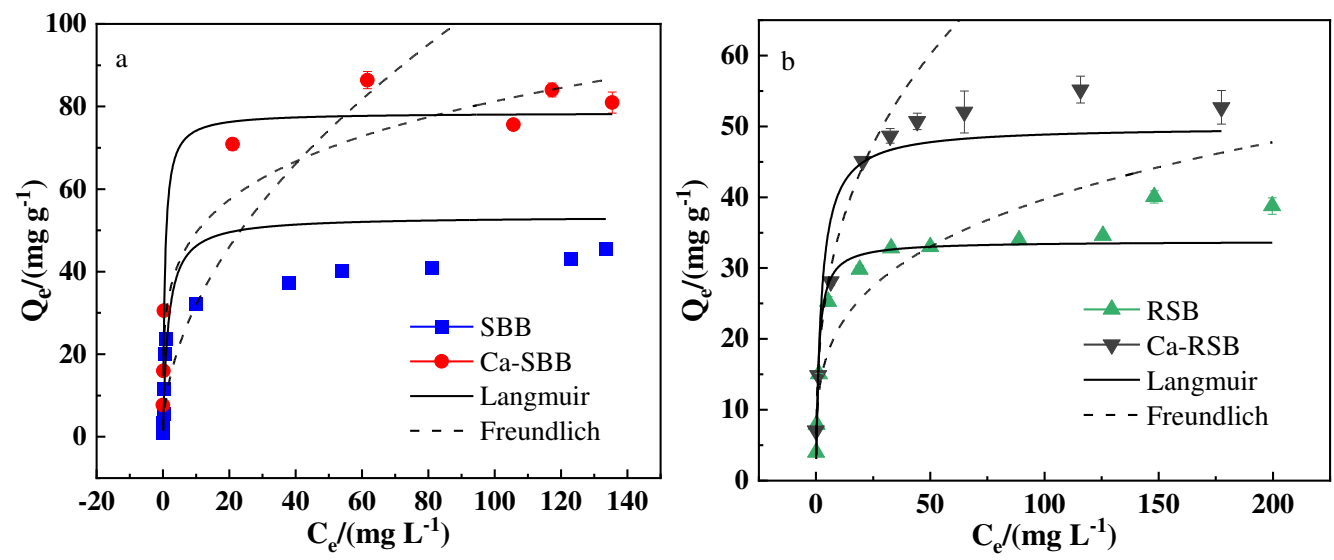

Fig. 2 Sorption isotherm of $\mathrm{Cd}^{2+}$ on $\mathrm{SBB}, \mathrm{Ca}-\mathrm{SBB}$ (a) and RSB, Ca-RSB (b), respectively. $\mathrm{Q}_{\mathrm{e}}$ $\left(\mathrm{mg} \mathrm{g}^{-1}\right)$ is the absorption capacity at equilibrium; $\mathrm{C}_{\mathrm{e}}\left(\mathrm{mg} \mathrm{L}^{-1}\right)$ is the equilibrium solution concentration

Table 2 The regression parameters of Langmuir and Freundlich models for adsorption isotherm

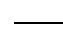
of $\mathrm{Cd}^{2+}$ onto biochars

Biochars

Langmuir parameters

\begin{tabular}{lll}
\hline $\mathrm{Q}_{\max }$ & $\mathrm{B}$ & $\mathrm{R}^{2}$
\end{tabular}

$\mathrm{mg} \mathrm{g}^{-1} \quad \mathrm{~L} \mathrm{mg}^{-1}$
Freundlich parameters

\begin{tabular}{lll}
\hline $1 / \mathrm{n}$ & $\mathrm{K}$ & $\mathrm{R}^{2}$ \\
& & \\
\end{tabular}

0.52

9.59

0.601

$0.27 \quad 11.63$

0.994 
Ca-SBB

78.49

1.70

0.983

0.22

30.09

0.941

Ca-RSB

49.96

0.435

0.990

0.34

15.86

0.983

209 Note: $\mathrm{Q}_{\max }$ is the maximum adsorption capacity $\left(\mathrm{mg} \mathrm{g}^{-1}\right)$; B is the Langmuir constant concerned

210 with the $\mathrm{Cd}$ absorption energy $\left(\mathrm{L} \mathrm{mg}^{-1}\right) ; \mathrm{N}$ is the Freundlich constant concerned with surface

211 heterogeneity; $\mathrm{K}$ is the Freundlich constant concerned with the $\mathrm{Cd}$ absorption capacity

212 3.1.3. Desorption

213 The distribution of desorption rates of $\mathrm{Cd}^{2+}$ was illustrated in Fig. 3. Compared to SBB and

$214 \mathrm{RSB}$, the average desorption efficiencies for $\mathrm{Ca}-\mathrm{SBB}$ and $\mathrm{Ca}-\mathrm{RSB}$ obtained with $0.1 \mathrm{~mol} \mathrm{~L}^{-1} \mathrm{NaNO}_{3}$

215 solution specifically decreased by $97.4 \%$ and $98.2 \%$, respectively.

216

217

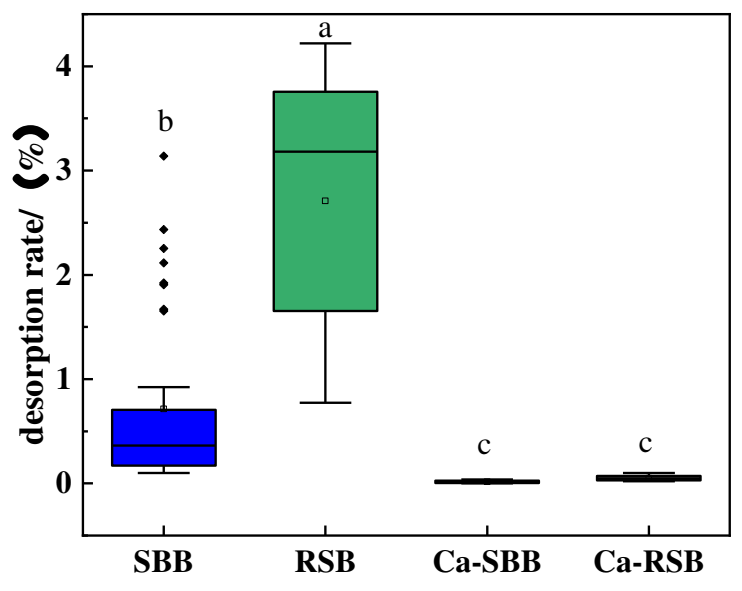

Fig. 3 The distribution of desorption rates of $\mathrm{Cd}^{2+}$ onto biochars

3.2. Relative distribution of adsorption mechanisms

As shown in Table 3 and Fig. 4, $\mathrm{Q}_{\mathrm{cmp}}$ formed the biggest fraction in SBB, followed by $\mathrm{Q}_{\mathrm{co}}$ and $\mathrm{Q}_{\mathrm{cme}}$, with $43.24 \%, 25.93 \%$ and $21.14 \%$ compared to the total adsorption, respectively. Conversely, $\mathrm{Q}_{\mathrm{cme}}$ accounted for the largest part in RSB, followed by $\mathrm{Q}_{\mathrm{cmp}}$, with $43.00 \%$ and $31.69 \%$ in comparison with the total adsorption, respectively. $\mathrm{After} \mathrm{Ca}(\mathrm{OH})_{2}$ modification, the $\mathrm{Q}_{\mathrm{cme}}$ value of Ca-SBB and Ca-RSB specifically increased by $162.0 \%$ and $217.4 \%$ compared to SBB and RSB, respectively. The contribution of $\mathrm{Q}_{\mathrm{cme}}$ to the total absorption of Ca-SBB and Ca-RSB increased from 
$21.14 \%$ and $43.00 \%$ to $34.93 \%$ and $61.91 \%$, respectively. Moreover, $\mathrm{Q}_{\mathrm{cmp}}$ of Ca-SBB was the dominant value, since it increased by $82.73 \%$ compared to SBB. However, $\mathrm{Q}_{\mathrm{cmp}}$ value of Ca-RSB decreased by $23.50 \%$ compared to RSB. Furthermore, $\mathrm{Q}_{\text {co }}$ value of Ca-SBB and Ca-RSB decreased by $13.14 \%$ and $15.74 \%$ compared to SBB and RSB, respectively. Still and all, the $\mathrm{Q}_{c \pi}$ value of CaSBB decreased significantly compared to that of SBB, while the $\mathrm{Q}_{c \pi}$ value of Ca-RSB increased significantly compared to that of RSB.

Table 3 Absorption capacity of $\mathrm{Cd}^{2+}$ by each mechanism on biochars (mean \pm S.D., $\mathrm{n}=3$ )

\begin{tabular}{lcccc}
\hline Biochar & $\mathrm{Q}_{\mathrm{cme}}\left(\mathrm{mg} \mathrm{g}^{-1}\right)$ & $\mathrm{Q}_{\mathrm{cmp}}\left(\mathrm{mg} \mathrm{g}^{-1}\right)$ & $\mathrm{Q}_{\mathrm{co}}\left(\mathrm{mg} \mathrm{g}^{-1}\right)$ & $\mathrm{Q}_{\mathrm{c} \pi}\left(\mathrm{mg} \mathrm{g}^{-1}\right)$ \\
\hline SBB & $11.55 \pm 0.05 \mathrm{~d}$ & $23.63 \pm 0.55 \mathrm{~b}$ & $14.16 \pm 0.30 \mathrm{a}$ & $5.29 \pm 0.76 \mathrm{a}$ \\
RSB & $19.41 \pm 0.20 \mathrm{c}$ & $14.30 \pm 1.79 \mathrm{c}$ & $8.07 \pm 0.15 \mathrm{c}$ & $3.36 \pm 0.10 \mathrm{~b}$ \\
Ca-SBB & $30.26 \pm 0.72 \mathrm{~b}$ & $43.18 \pm 0.89 \mathrm{a}$ & $12.30 \pm 0.23 \mathrm{~b}$ & $0.90 \pm 0.60 \mathrm{c}$ \\
Ca-RSB & $36.66 \pm 0.29 \mathrm{a}$ & $10.94 \pm 0.35 \mathrm{~d}$ & $6.80 \pm 0.35 \mathrm{~d}$ & $4.81 \pm 0.75 \mathrm{a}$ \\
\hline
\end{tabular}

234 indicate that the differences in the absorption capacity of $\mathrm{Cd}^{2+}$ by each mechanism on biochars in 235 the same treatment is significant $(\mathrm{P}<0.05)$ 


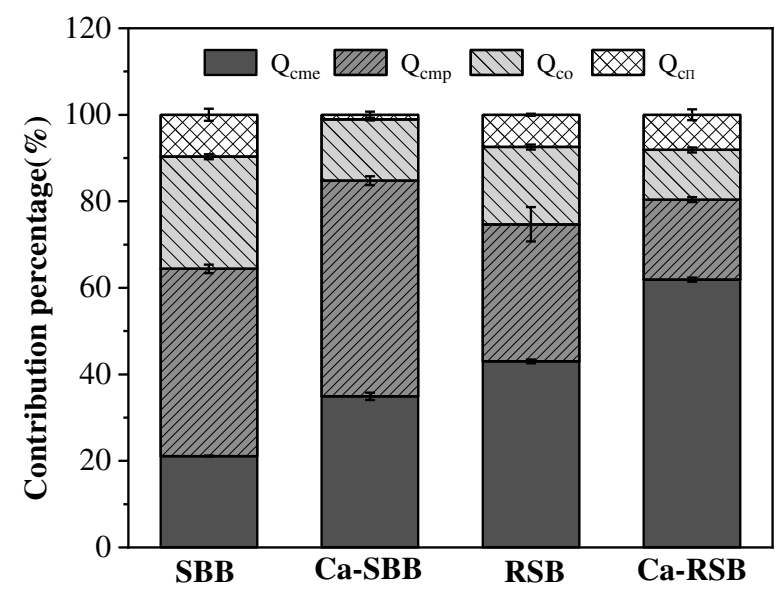

238 Fig. 4 The contribution percentage of different mechanisms to $\mathrm{Cd}^{2+}$ sorption on biochars.

4. Discussion

The isotherm results indicated that SBB had greater adsorption capacity and lower desorption

efficiency than RSB. The isotherm adsorption data of SBB conformed to Langmuir model, while that of RSB fitted both Langmuir and Freundlich model. It indicated that the $\mathrm{Cd}^{2+}$ adsorption on SBB followed a monolayer absorption mechanism, while on RSB it was not just monolayer, but it followed a multilayer absorption ( $\mathrm{Li}$, et al. 2017). The Freundlich constant $1 / \mathrm{n}$ is concerned with the surface inhomogeneity of the adsorbent. When $1 / \mathrm{n}$ is less than one, it is good for chemical adsorption, otherwise it is good for physical adsorption(Lin, et al. 2017). Because the $1 / \mathrm{n}$ value of RSB was 0.27 , chemisorption was dominant in RSB.

In SBB, $\mathrm{Q}_{\mathrm{cmp}}$ accounts for the largest proportion, followed by $\mathrm{Q}_{\mathrm{co}}$ and $\mathrm{Q}_{\mathrm{cme}}$. $\mathrm{Q}_{\mathrm{cme}}$ contributed the most to the total adsorption of $\mathrm{Cd}^{2+}$ in RSB, followed by $\mathrm{Q}_{\mathrm{cmp}}$. The tested biochars were scanned by XRD, SEM-EDS and FTIR before and after $\mathrm{Cd}^{2+}$ adsorption. Peaks of $\mathrm{CdCO}_{3}$ were found in $\mathrm{XRD}$ after $\mathrm{Cd}^{2+}$ adsorption both in SBB and RSB, indicating that the major precipitate was $\mathrm{CdCO}_{3}$ 
$\mathrm{O}$ and $\mathrm{Ca}$ (Fig. S1).

Metal ions on the surface of the biochar can be directly electrostatically adsorbed, or form complexes with oxygen-containing functional groups (e.g., $-\mathrm{COOM}+,-\mathrm{OM}+,-\mathrm{COOMOOC}-,-$ OMO-), or form precipitates with anions (e.g., CaCO3) (Yang, et al. 2019). These ions could be exchanged with $\mathrm{Cd} 2+$ during the sorption process. In $\mathrm{RSB}$, the dominance of $\mathrm{K}^{+}$were released, since the proportion of $\mathrm{K}^{+}$contribution was $87.0 \%$ to $\mathrm{Q}_{\mathrm{cme}}$ in $\mathrm{RSB}$. The total amount of $\mathrm{K}$ in RSB was 3.06 times larger than that in SBB (Table S1). Both XRD (Fig. 5) and SEM-EDS results (Fig. S1) also demonstrated that RSB was rich in K. Similar findings have been reported, suggesting the significance of ions exchange in $\mathrm{Cd}^{2+}$ adsorption (Huang, et al. 2020; Zhang, et al. 2015). Remarkably, ion-exchange has been reported to contribute up to $79.5 \%$ of Cd sorption by hyacinth biochar (Zhang, et al. 2015) and up to $44.49 \%$ by rice-husk biochars (Huang, et al. 2020).

In addition, the oxygen-containing functional groups on the surface of biochar can adsorb cadmium through complexation (Xia, et al. 2019). FTIR was adopted to study the changes of functional groups before and after $\mathrm{Cd}^{2+}$ adsorption (Fig. S2). In general the large peak at $3400 \mathrm{~cm}^{-1}$ was $\mathrm{H}$-bonded $\mathrm{OH}$ and the intense peak at $1600 \mathrm{~cm}^{-1}$ was esters $\mathrm{C}=\mathrm{O}$ or aromatic $\mathrm{C}=\mathrm{C}$. The peak of $1090 \mathrm{~cm}^{-1}$ was most probably concerned with lignin derivative C-O. In addition, the peak of 1270 $\mathrm{cm}^{-1}$ was most probably concerned with carboxyl $\mathrm{O}-\mathrm{H}$, while the peak at $1385 \mathrm{~cm}^{-1}$ was related to phenolic O-H (Drosos, et al. 2014). The carboxyl O-H and phenolic O-H of SBB and RSB decreased after $\mathrm{Cd}$ adsorption. Besides, the $\mathrm{Cd}^{2+}$ coordination with $\pi$-bonds such as $-\mathrm{CH}$ and $\mathrm{C}=\mathrm{C}$ was also the reason for $\mathrm{Cd}^{2+}$ adsorption on biochars ( $\mathrm{Wu}$, et al. 2019). The peak of $1450 \mathrm{~cm}^{-1}$ was related to aliphatic $\mathrm{C}-\mathrm{H}$ and the one of $1350 \mathrm{~cm}^{-1}$ was possibly attributed to methyl C-H $\left(\mathrm{R}-\mathrm{O}-\mathrm{CH}_{3}\right)($ Drosos, et al. 2009; Drosos, et al. 2014; Sui, et al. 2020). The contribution of $\mathrm{Q}_{c \pi}$ to total absorption of SBB 
and RSB were $9.69 \%$ and $7.44 \%$, respectively (Fig. 4), indicating that $\mathrm{Cd}^{2+}-\pi$ coordination influenced the $\mathrm{Cd}^{2+}$ adsorption mechanisms.

The isotherm results also indicated that compared with the original biochar (SBB, RSB), alkalimodified biochars (Ca-SBB and Ca-RSB) had greater adsorption capacities, faster adsorption kinetics and lower desorption efficiencies. However, it was interesting that the response mechanism of the two kinds of straw biochars to alkali modification was different.

$\mathrm{Ca}(\mathrm{OH})_{2}$ modification both effectively enhanced the adsorption capacity resulted from ion exchange mechanism on SBB and RSB (Table 3 and Fig. 4). Cation exchange capacity (CEC) is a major indicator of $\mathrm{Cd}^{2+}$ adsorption when ion exchange is the predominant mechanism(Yang, et al. 2019). Higher CEC was obtained in alkali-modified biochars than the original biochars (Table S1).

Consistently, good correlation was observed between $\mathrm{Q}_{\mathrm{cme}}$ and CEC (Fig. S3). The dominance of $\mathrm{Ca}^{2+}$ was found in $\mathrm{Ca}-\mathrm{SBB}$ and $\mathrm{Ca}-\mathrm{RSB}$, since the contribution proportions of $\mathrm{Ca}^{2+}$ in $\mathrm{Ca}-\mathrm{SBB}$ and Ca-RSB were $37.9 \%, 70.7 \%$ to $\mathrm{Q}_{\mathrm{cme}}$, respectively, higher than that in SBB and RSB (Table S2). Alkali-modified biochars also contained more Ca than the original biochars (Table S1). Moreover, metal ion exchange formed the biggest fraction in $\mathrm{RSB}$ and $\mathrm{Ca}-\mathrm{RSB}$. Although $\mathrm{Ca}(\mathrm{OH})_{2}$ modification improved the ion exchange effect, the desorption rates of Ca-SBB and Ca-RSB were extremely low (Fig. 3). The reason for this may be due to the fact that the ions exchanged with cadmium derived mainly from organic complexes, containing functional groups, and mineral precipitation rather than from direct electrostatic attraction.

After $\mathrm{Cd}^{2+}$ adsorption, peaks of $\mathrm{CdCO}_{3}$ were found in $\mathrm{Ca}-\mathrm{SBB}$ and $\mathrm{Ca}-\mathrm{RSB}$ (Fig. 5). $\mathrm{CdCO}_{3}$ precipitation was also reported by Cui, et al. (2016). Likewise, compared with the original biochar, white granular crystals were observed in the SEM image of Cd-loaded biochars, especially SBB $+\mathrm{Cd}$, 
$\mathrm{Ca}-\mathrm{SBB}+\mathrm{Cd}$ and $\mathrm{Ca}-\mathrm{RSB}+\mathrm{Cd}$. elements detected by EDS spectrum mainly included $\mathrm{Cd}, \mathrm{C}, \mathrm{O}$ and $\mathrm{Ca}$ (Fig. S1). In addition, minerals precipitation formed the biggest fraction in SBB and Ca-SBB (Table 3 and Fig. 4). $\mathrm{Ca}(\mathrm{OH})_{2}$ modification effectively enhanced the $\mathrm{Q}_{\mathrm{cmp}}$ value of SBB. However, the $\mathrm{Q}_{\mathrm{cmp}}$ value of Ca-SBB decreased significantly compared to that of SBB. Differences of $\mathrm{Q}_{\mathrm{cmp}}$ between SBB and RSB after modification were related to the elemental and mineral composition differences of RSB and SBB. For example, SBB contained more $\mathrm{Ca}$ and soluble $\mathrm{CO}_{3}{ }^{2-}$ than $\mathrm{RSB}$, while RSB had more $\mathrm{K}$ than SBB (Table S1). The XRD patterns indicated that $\mathrm{CaCO}_{3}$ and $\mathrm{CaHPO}_{4}$ were the main crystals in $\mathrm{SBB}$, while $\mathrm{KCl}$ and $\mathrm{CaCO}_{3}$ were the main crystals in $\mathrm{RSB}$. After $\mathrm{Ca}(\mathrm{OH})_{2}$ modification, the main compound for $\mathrm{Ca}-\mathrm{SBB}$ was $\mathrm{CaCO}_{3}$, while for $\mathrm{Ca}-\mathrm{RSB}$ the main compounds were both $\mathrm{CaCO}_{3}$ and $\mathrm{KCl}$ (Fig. 5). SBB had higher $\mathrm{pH}$ than $\mathrm{RSB}$. $\mathrm{Ca}(\mathrm{OH})_{2}$ modification effectively enhanced the $\mathrm{pH}$ value of SBB, but had no significant effect on RSB (Table S1). The $\mathrm{pH}$ value is an important indicator of $\mathrm{Q}_{\mathrm{cmp}}$. Consistently, good correlation was observed between $\mathrm{Q}_{\mathrm{cmp}}$ and $\mathrm{pH}$ (Fig. S4).

$\mathrm{Ca}(\mathrm{OH})_{2}$ modification remarkably decreased $\mathrm{Q}_{\mathrm{co}}$ because of the changes of functional groups such as $-\mathrm{OH}$, and $-\mathrm{COOH}$ (Fig. S2). Ca-SBB had less carboxylic $\mathrm{OH}$ than $\mathrm{SBB}$, since $\mathrm{Ca}$ would bind carboxyl groups. However, it had more phenolic OH than SBB, which revealed structural differences due to the alkali modification. Ca-RSB had less carboxylic $\mathrm{OH}$ and phenolic $\mathrm{OH}$ than RSB, which showed a difference in structure from SBB and also different mechanism of the biochar formation due to the $\mathrm{Ca}(\mathrm{OH})_{2}$ modification. After the $\mathrm{Cd}^{2+}$ interaction, the band intensities of carboxylic $\mathrm{OH}$ as well as phenolic $\mathrm{OH}$ were decreased for SBB, Ca-SBB and RSB. Therefore, functional groups such as $-\mathrm{OH}$, and $-\mathrm{COOH}$, seem to be mainly responsible for $\mathrm{Cd}^{2+}$ complexation. However, following $\mathrm{Cd}$ absorption in $\mathrm{Ca}-\mathrm{RSB}$, only the band intensity of phenolic $\mathrm{OH}$ was 
decreased, while carboxylic $\mathrm{OH}$ was not further reduced. This finding suggested that $\mathrm{Cd}$ application may result in $\mathrm{Ca}$ desorption and $\mathrm{Cd}$ adsorption in the material but the overall carboxylate binding balance remained unchanged. This result was in line with the adsorption mechanism presented in Table 3, which showed that cation exchange was the main mechanism of Cd binding in Ca-RSB (36.66 $\mathrm{mg} \mathrm{g}^{-1}$ ). The contribution of $\mathrm{Q}_{\mathrm{c} \pi}$ to the total absorption of the tested biochars was in the range of $1.02 \%$ to $9.06 \%$ (Fig. 4 ), indicating that $\mathrm{Cd}^{2+}-\pi$ coordination influenced the $\mathrm{Cd}^{2+}$ adsorption. As a matter of fact, $\mathrm{Q}_{\mathrm{c} \pi}$ value of Ca-SBB was much lower than that of Ca-RSB (Table 3). The reason for this change was the chemical alteration of RSB after modification as revealed by the $\mathrm{C} / \mathrm{N}$ ratio differences between RSB and Ca-RSB (Table S1). Actually the C/N ratio for Ca-RSB was almost 2.6 times higher than that of RSB (Table S1).High C/N ratio is the result of a hydrophobic material, not accessible to microbial decay (Brust 2019).
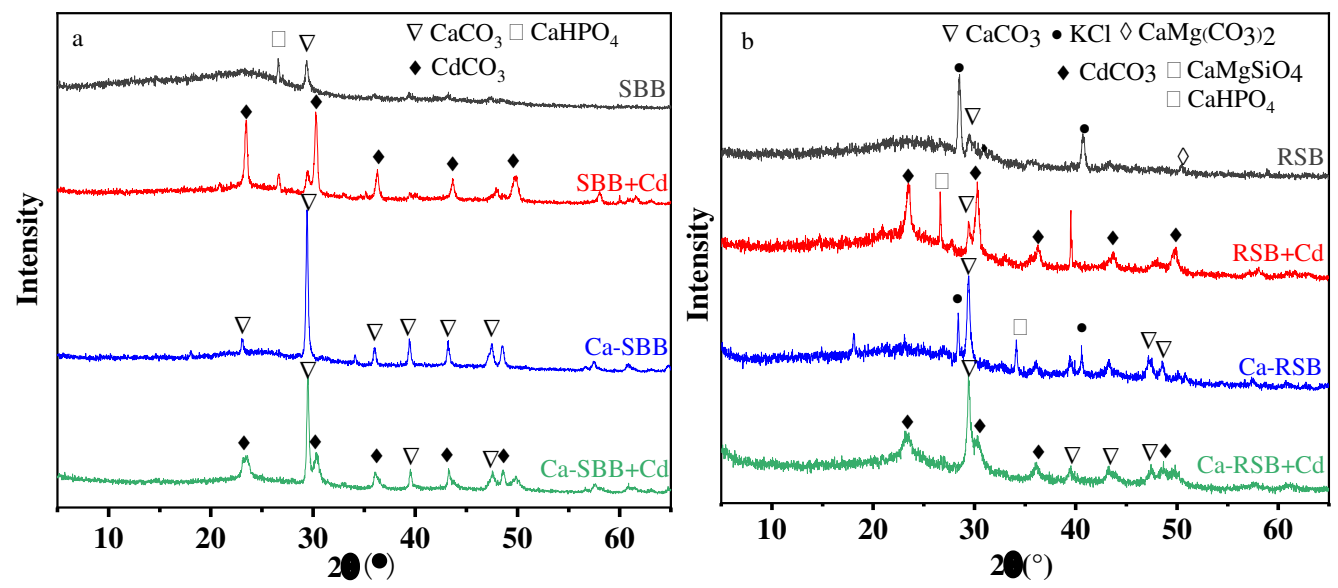

Fig. 5 XRD spectra of SBB, Ca-SBB (a) and RSB, Ca-RSB (b) before and after $\mathrm{Cd}^{2+}$ adsorption, respectively

\section{Conclusions}

Compared with the original biochar (SBB, RSB), alkali-modified biochars (Ca-SBB and CaRSB) had greater adsorption capacities, faster adsorption rates and lower desorption efficiencies. 
The $\mathrm{Cd}^{2+}$ absorption mechanism of the tested biochars mainly included mineral co-precipitation, ion exchange, complexation with functional groups and $\mathrm{Cd}^{2+}-\pi$ coordination. Ion exchange and precipitation mechanisms dominated $\mathrm{Cd}^{2+}$ sorption on $\mathrm{RSB}$, while precipitation and functional groups complexation mechanisms dominated $\mathrm{Cd}^{2+}$ sorption on SBB. After $\mathrm{Ca}(\mathrm{OH})_{2}$ modification, the interaction between $\mathrm{Cd}^{2+}$ and minerals (precipitation and ion exchange) was the main $\mathrm{Cd}^{2+}$ adsorption mechanism on alkali-modified biochars (Ca-SBB, Ca-RSB). Also, the response mechanism of the two kinds of straw biochars to alkali modification was different. These findings suggest that alkali-modified biochars exhibit a great potential for heavy metal remediation.

\section{Ethical approval}

The authors declare that the submitted manuscript is original and unpublished elsewhere, and that this manuscript complies with the Ethical Rules applicable for this journal.

\section{Consent to participate}

All participants have been involved directly or indirectly in the research itself.

\section{Consent to publish}

All the authors listed in the manuscript have agreed for authorship, read, and approved the manuscript and given consent for submission and subsequent publication of the manuscript. The order of authorship has been approved by all named authors prior to submission, and the name of the corresponding author has been agreed by all the authors. 
Authors contributions

Yaxin Kang: Conceptualization, Software, Investigation, Data Curation, Formal analysis , Visualization, Writing - Original Draft. Yi Zhou: Investigation, Resources. Hao Li: Investigation. Shanguo Chen: Investigation. Fenghua Tian: Investigation. Lianqing Li: Methodology, Validation, Writing - Review \& Editing, Funding acquisition, Project administration. Marios Drosos: Writing - Review \& Editing, Formal analysis. Genxing Pan: Supervision. Stephen Joseph: Formal analysis.

\section{Funding}

This study was financially supported by the National Natural Science Foundation of China (NSFC) (42077148), the National Key Research and Development Program of China (2016YFD0800306).

\section{Competing interests}

The authors declare no conflict of interest.

Availability of data and materials

All data generated or analyzed during this study are included in this manuscript and its supplementary information files. All the materials used during the current study are available from the corresponding author on reasonable request.

\section{References}



Biochar as a sorbent for contaminant management in soil and water: A review. Chemosphere 99: 19-33. http://dx.doi.org/10.1016/j.chemosphere.2013.10.071

Ahmed M B, Zhou J L, Ngo H H, Guo W, Chen M (2016) Progress in the preparation and application of modified biochar for improved contaminant removal from water and wastewater. Bioresour. Technol. 214: 836-851. http://dx.doi.org/10.1016/j.biortech.2016.05.057

Bian R J, Joseph S, Cui L Q, Pan G X, Li L Q, Liu X Y, Zhang A, Rutlidge H, Wong S W, Chia C, Marjo C, Gong B, Munroe P, Donne S (2014) A three-year experiment confirms continuous immobilization of cadmium and lead in contaminated paddy field with biochar amendment. J. Hazard. Mater. 272: 121-128. http://dx.doi.org/10.1016/j.jhazmat.2014.03.017

Bolan N, Kunhikrishnan A, Thangarajan R, Kumpiene J, Park J, Makino T, Kirkham M B, Scheckel K (2014) Remediation of heavy metal(loid)s contaminated soils - To mobilize or to immobilize? J. Hazard. Mater. 266: 141-166. http://dx.doi.org/10.1016/j.jhazmat.2013.12.018

Brust G E (2019) Management Strategies for Organic Vegetable Fertility. In: Biswas, D and Micallef, S A (ed) Safety and Practice for Organic Food. Academic Press, pp 193-212

Burakov A E, Galunin E V, Burakova I V, Kucherova A E, Agarwal S, Tkachev A G, Gupta V K (2018) Adsorption of heavy metals on conventional and nanostructured materials for wastewater treatment purposes: A review. Ecotox. Environ. Safe. 148: 702-712. http://dx.doi.org/10.1016/j.ecoenv.2017.11.034

Cui X, Fang S, Yao Y, Li T, Ni Q, Yang X, He Z (2016) Potential mechanisms of cadmium removal from aqueous solution by Canna indica derived biochar. Sci. Total Environ. 562: 517-525. $\underline{\text { http://dx.doi.org/10.1016/j.scitotenv.2016.03.248 }}$

Drosos M, Jerzykiewicz M, Deligiannakis Y (2009) H-binding groups in lignite vs. soil humic acids: NICA-Donnan and spectroscopic parameters. J. Colloid Interface Sci. 332(1): 78-84. http://dx.doi.org/10.1016/j.jcis.2008.12.023

Drosos M, Leenheer J A, Avgeropoulos A, Deligiannakis Y (2014) H-binding of size- and polarityfractionated soil and lignite humic acids after removal of metal and ash components. Environ. Sci. Pollut. Res. 21(5): 3963-3971. http://dx.doi.org/10.1007/s11356-013-2302-9

Fu F L, Wang Q (2011) Removal of heavy metal ions from wastewaters: A review. J. Environ. Manage. 
Gaskin J W, Steiner C, Harris K, Das K C, Bibens B (2008) EFFECT OF LOW-TEMPERATURE PYROLYSIS CONDITIONS ON BIOCHAR FOR AGRICULTURAL USE. Trans. ASABE 51(6): 
supplemented with $\mathrm{Si}$ on $\mathrm{Cd}$ mobility and rice uptake over three rice growing seasons in an acidic Cd-tainted paddy from central South China. Sci. Total Environ. 709. http://dx.doi.org/10.1016/j.scitotenv.2019.136101

Tan X F, Liu Y G, Gu Y L, Xu Y, Zeng G M, Hu X J, Liu S B, Wang X, Liu S M, Li J (2016) Biocharbased nano-composites for the decontamination of wastewater: A review. Bioresour. Technol. 212: 318-333. http://dx.doi.org/10.1016/j.biortech.2016.04.093

Trakal L, Bingol D, Pohorely M, Hruska M, Komarek M (2014) Geochemical and spectroscopic investigations of $\mathrm{Cd}$ and $\mathrm{Pb}$ sorption mechanisms on contrasting biochars: Engineering implications. Bioresour. Technol. 171: 442-451. http://dx.doi.org/10.1016/j.biortech.2014.08.108

Wang R Z, Huang D L, Liu Y G, Zhang C, Lai C, Zeng G M, Cheng M, Gong X M, Wan J, Luo H (2018) Investigating the adsorption behavior and the relative distribution of $\mathrm{Cd} 2+$ sorption mechanisms on biochars by different feedstock. Bioresour. Technol. 261: 265-271. http://dx.doi.org/10.1016/j.biortech.2018.04.032

Wang Z, Liu G, Zheng H, Li F, Ngo H H, Guo W, Liu C, Chen L, Xing B (2015) Investigating the mechanisms of biochar's removal of lead from solution. Bioresour. Technol. 177: 308-317. http://dx.doi.org/10.1016/j.biortech.2014.11.077

Wilson K, Yang H, Seo C W, Marshall W E (2006) Select metal adsorption by activated carbon made from peanut shells. Bioresour. Technol. 97(18): 2266-2270. http://dx.doi.org/10.1016/j.biortech.2005.10.043

Woods W I, Falcao N P S, Teixeira W G (2006) Biochar trials aim to enrich soil for smallholders. Nature 443(7108): 144-144. http://dx.doi.org/10.1038/443144b

Wu J W, Wang T, Zhang Y S, Pan W P (2019) The distribution of Pb(II)/Cd(II) adsorption mechanisms on biochars from aqueous solution: Considering the increased oxygen functional groups by $\mathrm{HCl}$ treatment. Bioresour. Technol. 291: 7. http://dx.doi.org/10.1016/j.biortech.2019.121859

Xia Y, Yang T, Zhu N, Li D, Chen Z, Lang Q, Liu Z, Jiao W (2019) Enhanced adsorption of Pb(II) onto modified hydrochar: Modeling and mechanism analysis. Bioresour. Technol. 288. http://dx.doi.org/10.1016/j.biortech.2019.121593

Yang X D, Wan Y S, Zheng Y L, He F, Yu Z B, Huang J, Wang H L, Ok Y S, Jiang Y S, Gao B (2019) Surface functional groups of carbon-based adsorbents and their roles in the removal of heavy 
metals from aqueous solutions: A critical review. Chem. Eng. J. 366: 608-621. http://dx.doi.org/10.1016/j.cej.2019.02.119

472 Yu W C, Lian F, Cui G N, Liu Z Q (2018) N-doping effectively enhances the adsorption capacity of biochar for heavy metal ions from aqueous solution. Chemosphere 193: 8-16. http://dx.doi.org/10.1016/j.chemosphere.2017.10.134

Zhang A F, Cui L Q, Pan G X, Li L Q, Hussain Q, Zhang X H, Zheng J W, Crowley D (2010) Effect of biochar amendment on yield and methane and nitrous oxide emissions from a rice paddy from Tai Lake plain, China. Agric. Ecosyst. Environ. 139(4): 469-475. http://dx.doi.org/10.1016/j.agee.2010.09.003

479 Zhang F, Wang X, Yin D X, Peng B, Tan C Y, Liu Y G, Tan X F, Wu S X (2015) Efficiency and mechanisms of $\mathrm{Cd}$ removal from aqueous solution by biochar derived from water hyacinth 

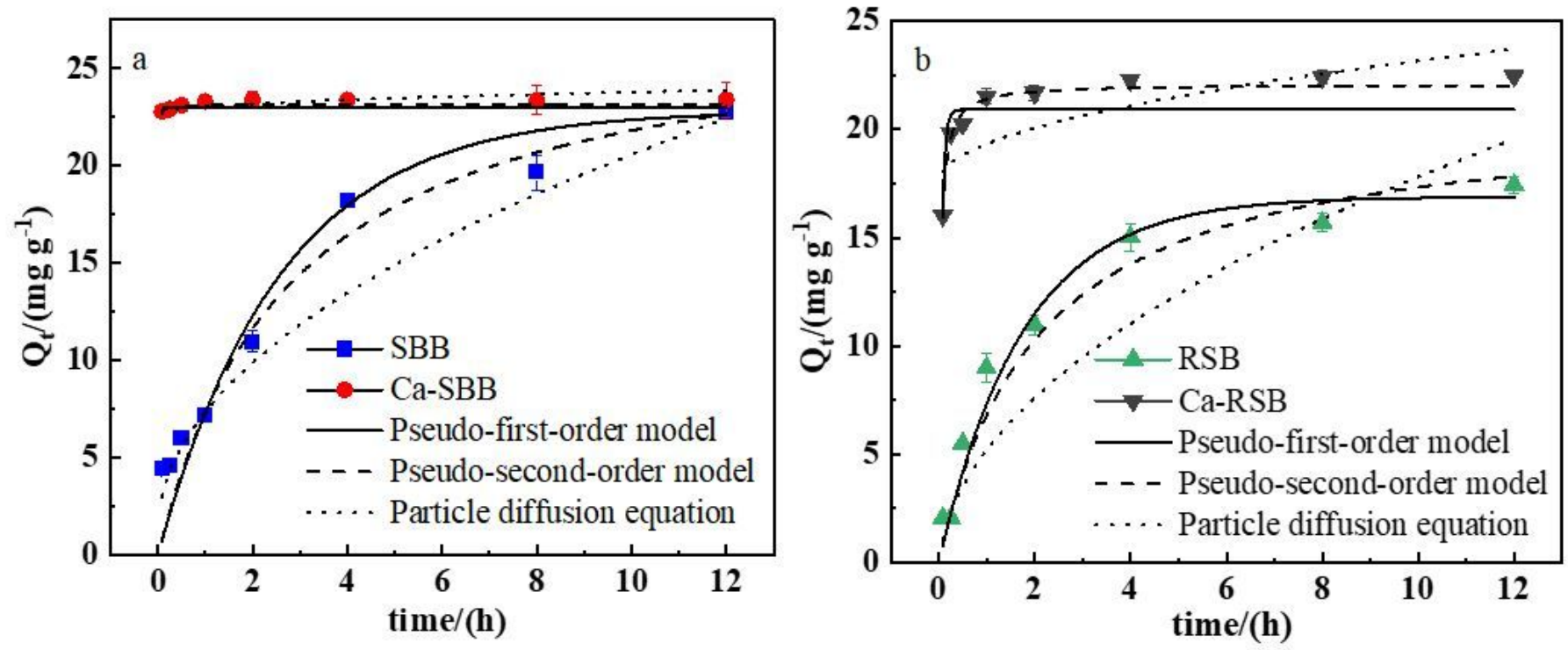

Figure 1

Sorption kinetic of Cd2+ on SBB, Ca-SBB (a) and RSB, Ca-RSB (b), respectively. Qt (mg g-1) is the amount of metal adsorbed per unit weight of adsorbent
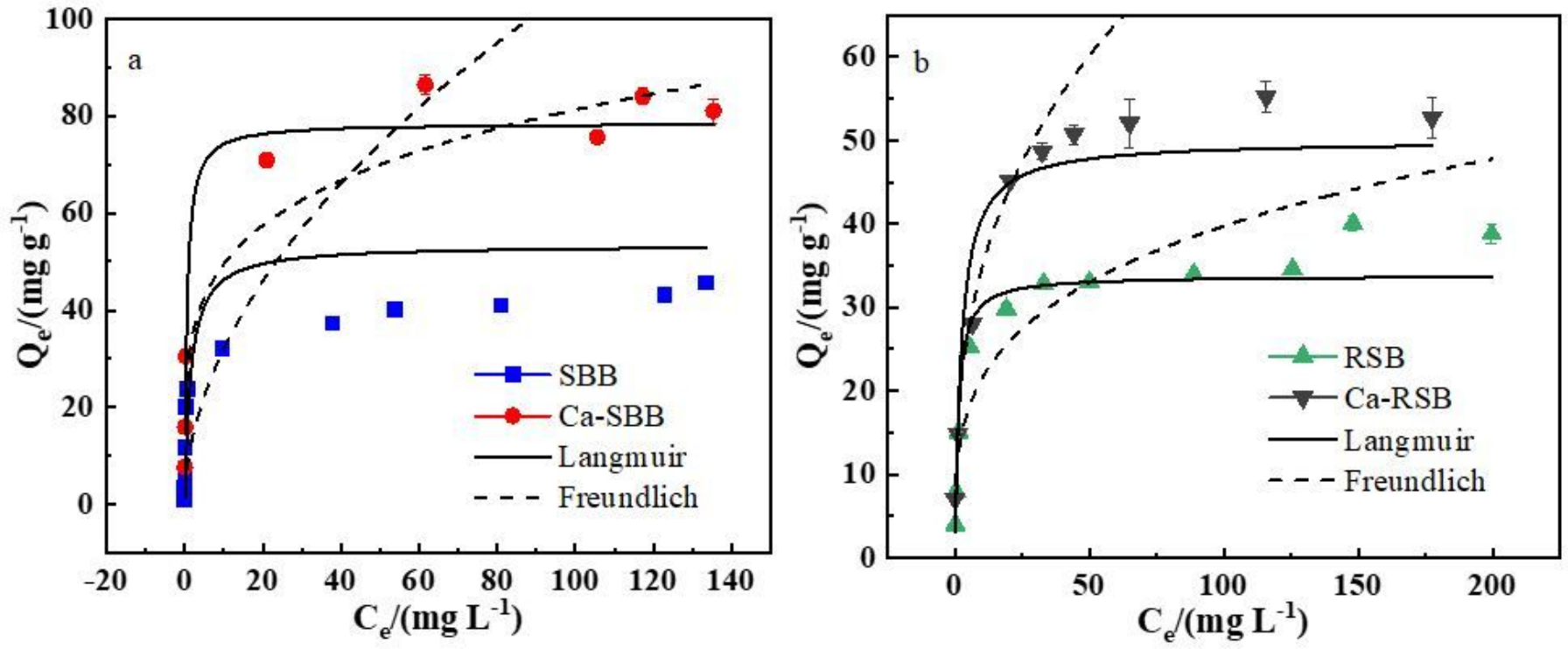

Figure 2

Sorption isotherm of Cd2+ on SBB, Ca-SBB (a) and RSB, Ca-RSB (b), respectively. Qe (mg g-1) is the absorption capacity at equilibrium; $\mathrm{Ce}(\mathrm{mg} \mathrm{L}-1)$ is the equilibrium solution concentration 


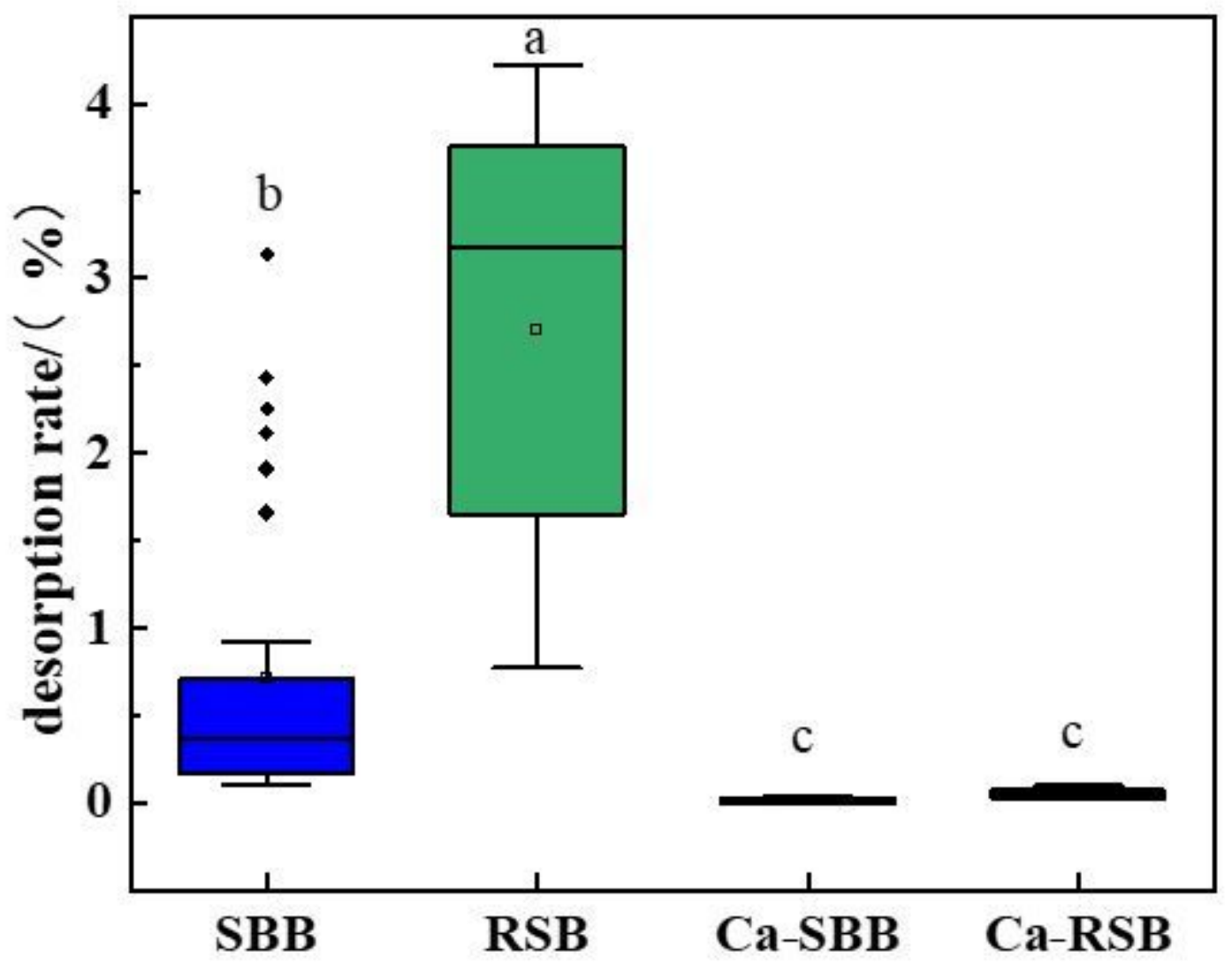

Figure 3

The distribution of desorption rates of $\mathrm{Cd} 2+$ onto biochars 


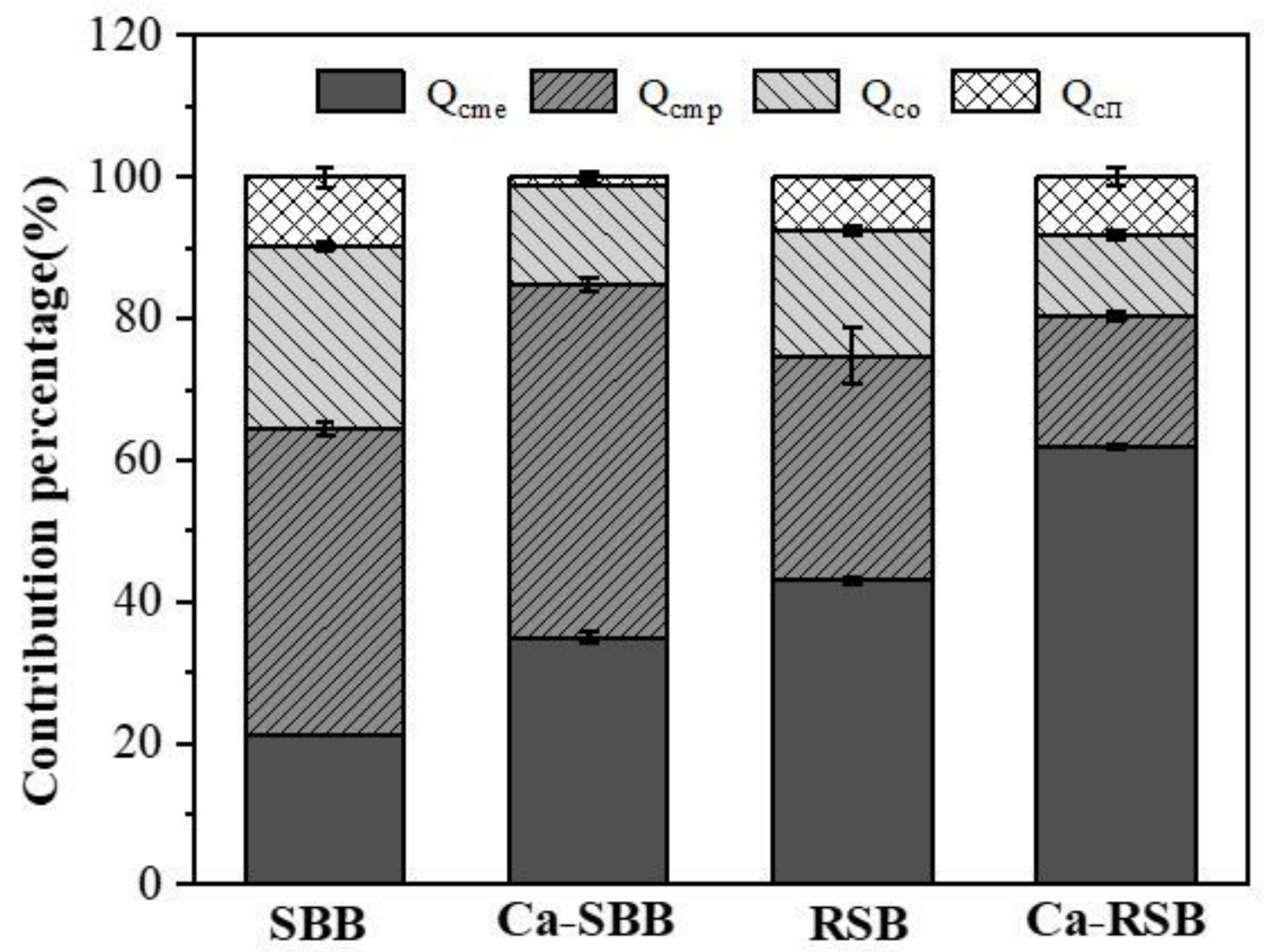

Figure 4

The contribution percentage of different mechanisms to $\mathrm{Cd} 2+$ sorption on biochars.
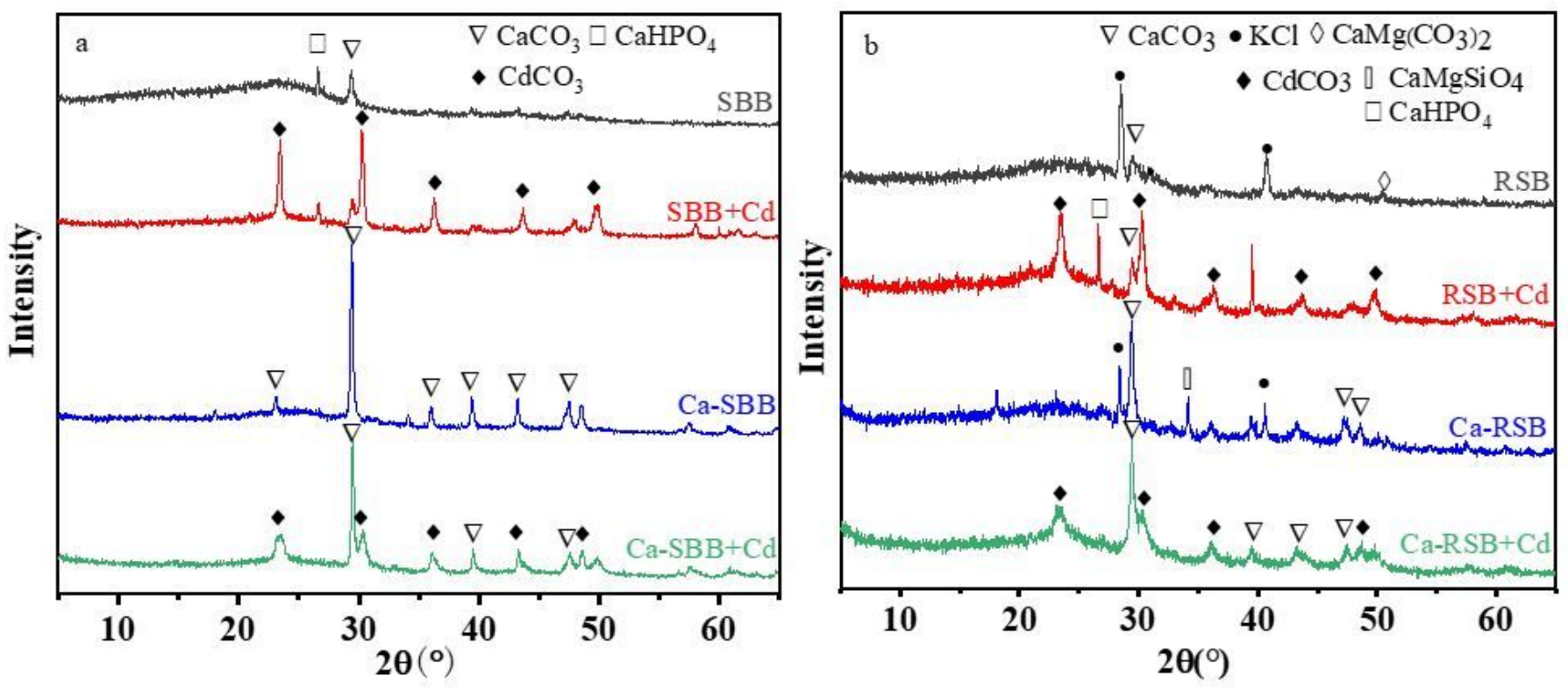
Figure 5

XRD spectra of SBB, Ca-SBB (a) and RSB, Ca-RSB (b) before and after Cd2+ adsorption, respectively

\section{Supplementary Files}

This is a list of supplementary files associated with this preprint. Click to download.

- Supplementarymaterial.docx 